\title{
Buccally displaced flap versus sub-epithelial connective tissue graft for peri-implant soft tissue augmentation: a pilot double-blind randomized controlled trial
}

\author{
Ninad Milind Padhye 1* $^{*}$, Lopa Kishor Mehta ${ }^{2}$ and Naveeta Yadav ${ }^{3}$
}

\begin{abstract}
Background: This article describes a novel surgical technique, the buccally displaced flap, for keratinized mucosa (KM) augmentation during implant uncovering. Furthermore, it clinically compares this technique with subepithelial connective tissue graft (SCTG) for peri-implant KM augmentation. Twelve weeks following implant placement, subjects were randomly divided for KM augmentation into group A (buccally displaced flap) and group B (SCTG). The width (WKM) and thickness (TKM) of the KM were assessed prior to the implant uncovering, 4 weeks and 1 year after implant loading. Post-operative pain assessment was performed using the Numeric Rating Scale.

Results: The study comprised of 20 implants that were uncovered in 20 subjects. For group A, the mean WKM increased from $0.98( \pm 0.23 \mathrm{~mm})$ to $3.01 \mathrm{~mm}( \pm 0.18 \mathrm{~mm})$, and the mean TKM increased from $1.45( \pm 0.13 \mathrm{~mm})$ to $2.21 \mathrm{~mm}( \pm 0.16 \mathrm{~mm})$ at 1 year. For group B, the mean WKM increased from $0.93( \pm 0.18 \mathrm{~mm})$ to $3.28 \mathrm{~mm}( \pm 0.13$ $\mathrm{mm})$, and the mean TKM increased from $1.41( \pm 0.15 \mathrm{~mm})$ to $2.25 \mathrm{~mm}( \pm 0.11 \mathrm{~mm})$ at 1 year. Post-operative pain was significantly higher for group B $4.15( \pm 1.35)$ as compared to group A $2.6( \pm 1.22)(p<0.001)$.

Conclusion: The buccally displaced flap increased the WKM and TKM during implant uncovering, with results comparable to SCTG. The main advantages of the technique were lack of sutures, maintenance of blood supply, reducing number of surgical sites, and it was relatively atraumatic with lesser post-operative pain.

Trial registration: Clinical trials registry—India CTRI/2019/09/021059. Date of registration—September 4, 2019, retrospectively registered.

Keywords: Connective tissue graft, Displaced flap, Peri-implant keratinized mucosa, Soft tissue augmentation, Surgical flaps
\end{abstract}

\footnotetext{
* Correspondence: ninadpadhye91@gmail.com

Previous presentation: A part of this study has been presented at the

European Association for Osseointegration Congress at Lisbon in September,

2019 as an oral communication. Subsequently, a brief abstract of the

presentation has been published in Clinical Oral Implants Research journal.

${ }^{1}$ Ceramco Dental Care, Andheri West, Mumbai, Maharashtra, India

Full list of author information is available at the end of the article
}

\section{Springer Open}

(c) The Author(s). 2020 Open Access This article is licensed under a Creative Commons Attribution 4.0 International License, which permits use, sharing, adaptation, distribution and reproduction in any medium or format, as long as you give appropriate credit to the original author(s) and the source, provide a link to the Creative Commons licence, and indicate if changes were made. The images or other third party material in this article are included in the article's Creative Commons licence, unless indicated otherwise in a credit line to the material. If material is not included in the article's Creative Commons licence and your intended use is not permitted by statutory regulation or exceeds the permitted use, you will need to obtain permission directly from the copyright holder. To view a copy of this licence, visit http://creativecommons.org/licenses/by/4.0/. 


\section{Background}

Hard and soft tissue deficiencies are a common occurrence as a result of long-term edentulism. Following tooth extraction, the degree of bone resorption can reach up to $50 \%$ of the original bone width in the first 2 years [1-3]. With substantial bone loss, a coronal shift in the mucogingival junction is also noted [4]. This potentially compromises the keratinized tissue dimensions for implant-based rehabilitations.

Although the role of keratinized mucosa (KM) for implant survival is still debatable, it has been established that the absence of KM impedes adequate oral hygiene maintenance [5]. An indirect correlation has been found between KM dimensions and plaque accumulation and gingival inflammation [6].

Traditionally, sub-epithelial connective tissue graft (SCTG) was harvested from the hard palate for periimplant soft tissue augmentations. However, this procedure often required a secondary surgical site to procure the autogenous graft, adding to the post-operative discomfort. Abrams [7] introduced the roll flap technique for soft tissue augmentation for edentulous ridges. This technique provided a vascular connective tissue pedicle graft that could minimize the donor site morbidity. Subsequently, several techniques have been suggested for implant site soft tissue augmentation such as modified palatal roll flap [8], apically positioned flap [9], splitfinger flap [10], tunnel exposure [11], and rotated palatal flap [12]. This study aims to describe the buccally displaced flap, a novel surgical technique for implant site soft tissue augmentation. Furthermore, it compares this technique to SCTG for peri-implant KM augmentation during implant uncovering.

\section{Materials and method}

This prospective double-blinded randomized controlled clinical trial was conducted in accordance with the ethical standards outline in the 1964 Declaration of Helsinki, as revised in 2008. Ethical clearance was attained, and the study was registered with the clinical trials registry.

\section{Surgical technique for buccally displaced flap (supplementary video)}

The surgical procedure was carried out during the implant uncovering stage 12 weeks after implant placement. Under local anaesthesia, bone sounding was performed on the crest of the ridge (Fig. 1a) using a UNC-15 probe (Hu-Friedy, USA), and the soft tissue thickness over the previously placed implant was found to be within the range of $2-4 \mathrm{~mm}$. Two parallel vertical incisions were placed, extending 3-4 $\mathrm{mm}$ on the palatal/ lingual surface of the edentulous crest. The parallel incisions were connected by a perpendicular incision on the palatal/lingual side (Fig. 1b). Partial thickness tissue dissection was then performed underneath the incisions extending till the mucogingival junction on the buccal side, and a partial thickness flap was reflected (Fig. 1c, d). The connective tissue over the implant was removed, and the implant was exposed using a curette (Hu-Friedy, USA) (Fig. 1e). The partial thickness flap was then displaced buccally and adapted over the surface (Fig. 1f). A

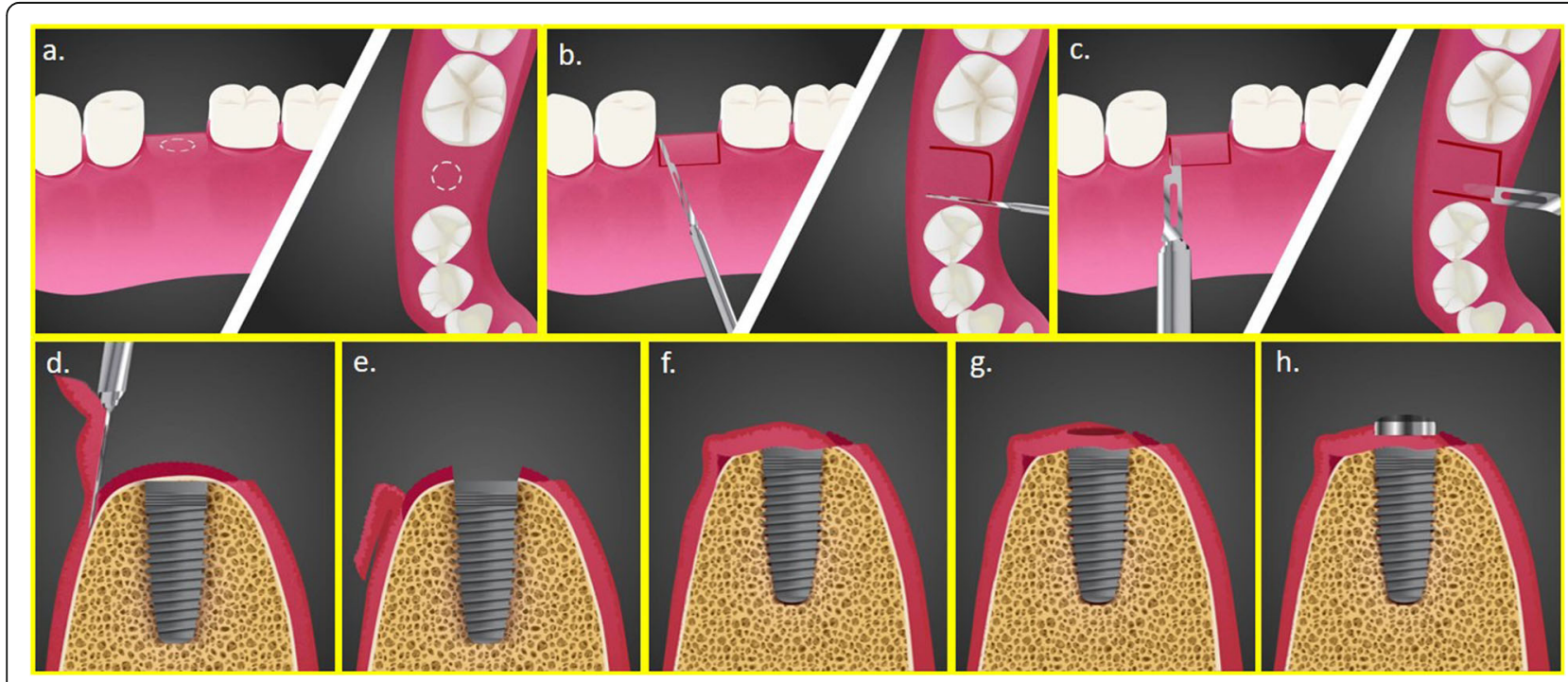

Fig. 1 Buccally displaced flap surgical technique. a Bone sounding. b Two parallel and one perpendicular incisions placed. c Partial thickness tissue dissection underneath the incisions. $\mathbf{d}$ Tissue dissection extending till the mucogingival junction on buccal side, and partial thickness flap reflected. e Connective tissue over the implant removed. f Partial thickness flap displaced buccally and adapted over the surface. $\mathbf{g} 3$ mm tissue punch. $\mathbf{h}$ Healing abutment to secure the flap in its new position 
3-mm tissue punch was made in the displaced flap over the implant surface (Fig. 1g). To secure the flap in its new position, a $3-5-\mathrm{mm}$ high healing abutment was placed through the punched flap into the implant (Fig. 1h).

\section{Surgical technique for sub-epithelial connective tissue graft}

Twelve weeks after implant placement, under local anaesthesia, a crestal incision was placed at the implant site. A full thickness mucoperiosteal flap was reflected to expose the implant. A 3-5-mm high healing abutment was placed into the implant. SCTG was harvested from the palate with a single incision technique and tucked buccally underneath the reflected flap. The graft and the flap were then stabilized using interrupted sutures.

\section{Study design}

Subjects were recruited for the study with the inclusion criteria: (1) > 21 years of age, (2) no medical contraindications and generally healthy patients, (3) missing teeth in the posterior region (premolar/molar), (4) no bone augmentation procedures required before or during implant placement, and (5) signed informed consent form for participation and permission to use obtained data for research purposes. Patients were excluded if they had (1) poor oral hygiene, (2) smoking or tobacco chewing habit, and (3) diabetes mellitus.

A standard sample size calculation determined that a minimum of 10 subjects per group with a total of 20 subjects were required for the difference between WKM and TKM values to be statistically significant when $\alpha=$ 0.05 , the power of the study set at $80 \%$, as determined by a study done by Temmerman et al. in 2018 [13]. Two-stage bone-level endosseous implants (Osstem TSIII, Osstem Implant Co., Busan, Korea) were placed in 20 subjects included for the study. Twelve weeks after the implant placement surgery, subjects were randomly divided into two groups, by envelope drawing, for soft tissue augmentation. Subjects of group A received augmentation using the buccally displaced flap (Fig. 2), and subjects of group B received augmentation using SCTG (Fig. 3) respectively. Treatment assignment was noted in the registration by the study monitor (N.Y.). Allocation concealment was performed using sequentially numbered sealed envelopes that were made by the study monitor using computer-generated random permuted block. The randomization envelope was opened prior to the surgical procedure. All the surgical procedures were carried out by a single operator (N.P.). Post-operatively, $400 \mathrm{mg}$ ibuprofen was prescribed to all the participants on an as-needed basis.

The width (WKM) and thickness (TKM) of the KM were the clinical parameters assessed for the included subjects. WKM was measured on the buccal aspect from the gingival margin to the mucogingival junction using a UNC-15 probe (Hu-Friedy, USA). The TKM was measured $2 \mathrm{~mm}$ apical to the free gingival margin on the buccal aspect using an endodontic reamer file. The parameters were assessed prior to the implant uncovering (baseline), 4 weeks and 1 year after implant loading. Post-operative pain assessment was performed 1 week following the implant uncovering using the Numeric Rating Scale $[14,15]$. The participants were instructed to select a number from 0 through 10 that best reflected

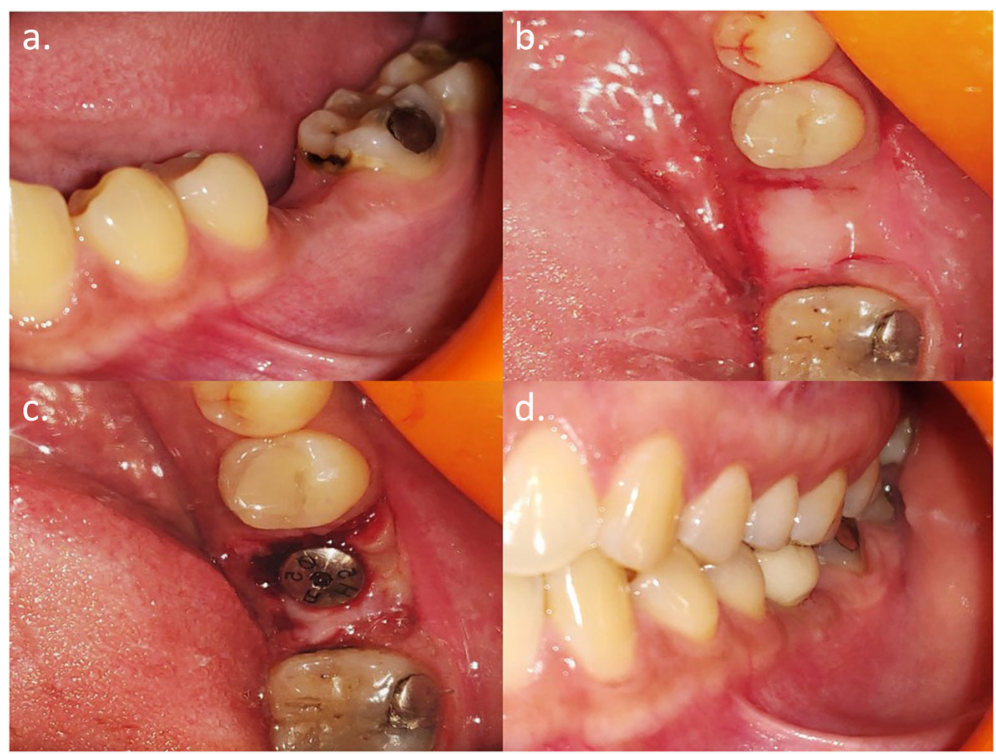

Fig. 2 Peri-implant keratinized mucosa augmentation for group A. a Pre-operative. b Incisions placed. c Flap displaced buccally and stabilized by a healing abutment. $\mathbf{d} 1$ year follow-up 


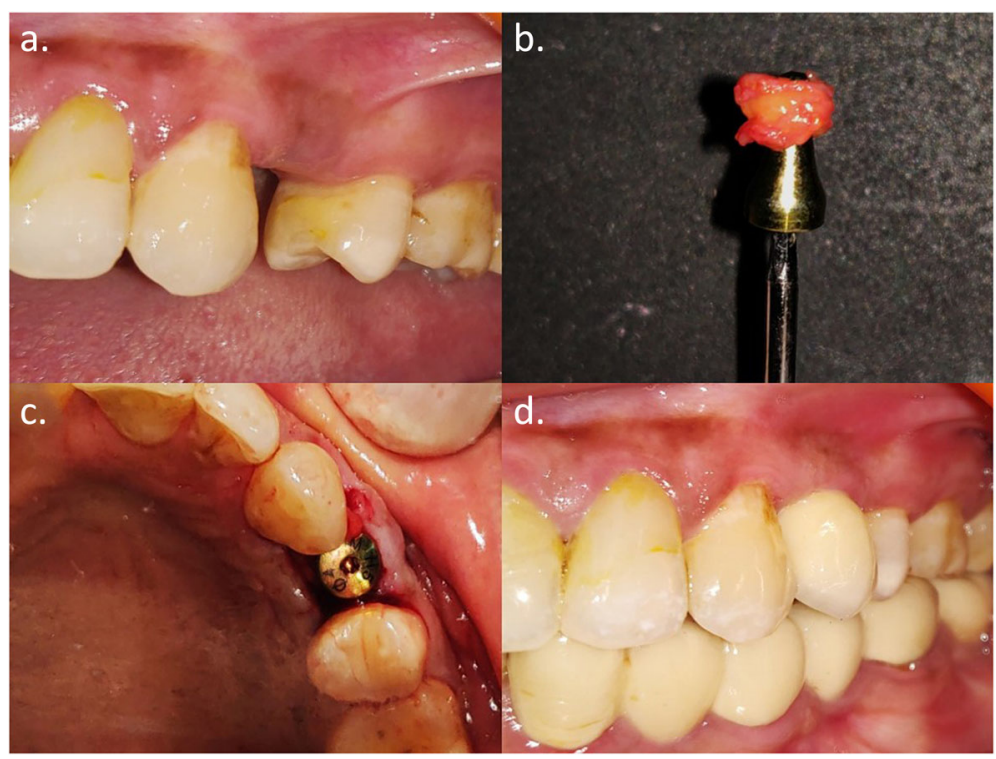

Fig. 3 Peri-implant keratinized mucosa augmentation for group B. a Pre-operative. b Sub-epithelial connective tissue graft harvested from hard palate. c Graft tucked buccally and healing abutment placed. $\mathbf{d} 1$ year follow-up

the intensity of pain, with 0 equalling no pain and 10 the worst pain. All the clinical assessments were done by a second operator (L.M.) who was blinded to the surgical procedure performed.

\section{Statistical analysis}

The recorded data was entered in Microsoft Excel (MS office version 2010) and tabulated. Data analysis was done using the Windows PC based software "MedCalc Statistical Software" version 13.3.1 (MedCalc Software bvba, Ostend, Belgium; http://www.medcalc.org; 2014). All testing was done at alpha 0.05 (95\% confidence limits). Intra- and inter-group comparison was performed using the paired and unpaired student $t$ test, respectively, considering normality assumption and homoscedasticity. Differences above the $95 \%$ confidence intervals were regarded as statistically significant.

\section{Results}

For this pilot study, a total of 20 implants placed in 20 subjects (13 females and 7 males) were included. The mean age of the study participants was $48 \pm 5.9$ years. No implants were lost or showed signs of periimplantitis during the follow-up period of 1 year.

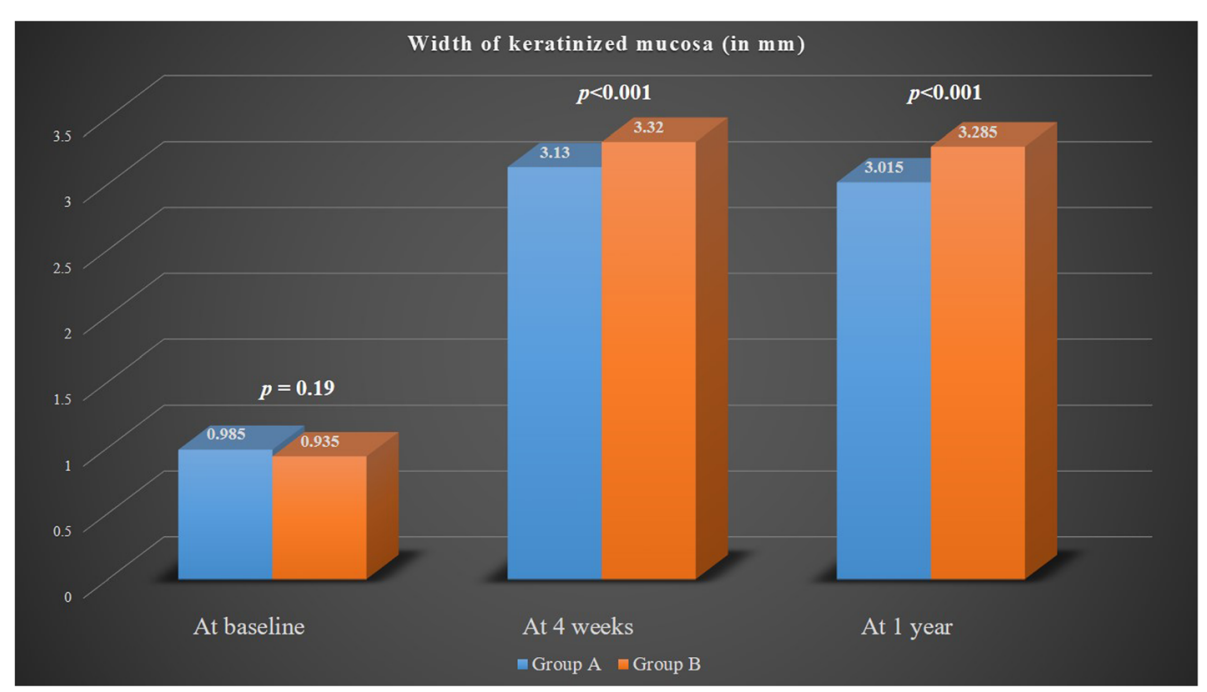

Fig. 4 Comparison of the width of keratinized mucosa between group A and group B at various time points 
At the time of implant uncovering, there was minimal WKM noted (group A, $0.98 \mathrm{~mm} \pm 0.23 \mathrm{~mm}$; group B, $0.93 \mathrm{~mm} \pm 0.18 \mathrm{~mm})(p=0.19)$. At 4 weeks and 1 year after implant loading, the WKM significantly increased for both the groups from baseline. The WKM at 4 weeks and 1 year for group B $(3.32 \mathrm{~mm} \pm 0.19 \mathrm{~mm}, 3.28 \mathrm{~mm} \pm 0.13$ $\mathrm{mm})$ was significantly higher than group A $(3.13 \mathrm{~mm} \pm$ $0.22 \mathrm{~mm}, 3.01 \mathrm{~mm} \pm 0.18 \mathrm{~mm})(p<0.001)$ (Fig. 4).

The mean TKM at baseline was $1.45 \mathrm{~mm} \pm 0.13 \mathrm{~mm}$ for group $\mathrm{A}$ and $1.41 \mathrm{~mm} \pm 0.15 \mathrm{~mm}$ for group $\mathrm{B}(p=$ $0.44)$. At 4 weeks, the TKM was considerably higher for group B $(2.44 \mathrm{~mm} \pm 0.26 \mathrm{~mm})$ as compared to group A $(2.26 \mathrm{~mm} \pm 0.31 \mathrm{~mm})(p<0.001)$. However, at 1 year, there was no statistically significant difference in TKM between group B $(2.25 \mathrm{~mm} \pm 0.11 \mathrm{~mm})$ and group A $(2.21 \mathrm{~mm} \pm 0.16 \mathrm{~mm})(p=0.29)$ (Fig. 5). Post-operative pain and discomfort according to the Numeric Rating Scale were significantly greater for subjects of group B $(4.15 \pm 1.35)$ as compared to group A $(2.6 \pm 1.22)(p<$ $0.001)$.

\section{Discussion}

Peri-implant soft tissue augmentation can be performed at various stages during the dental implant procedure such as prior to implant placement, in combination with bone augmentation, simultaneous with implant placement, at the temporization phase, during the phases of osseointegration, prior to delivery of the final reconstruction, or during the second stage surgery [16]. The proposed surgical procedure aimed at correcting the buccal keratinized mucosa deficiencies during the implant uncovering phase. Maintaining an adequate thickness of the marginal gingiva at an early phase of the implant uncovery is essential for the maintenance of peri-implant health and esthetics [17]. Transformation of a thin gingival biotype to thick gingival biotype results in a stable peri-implant soft tissue dimension [18]. An adequate width of keratinized mucosa attached to the underlying periosteum is essential for the overall longterm success of implant supported rehabilitation [12, 19].

The buccally displaced flap surgical technique was a combination of the Abram's roll technique [7] and the apically displaced flap [20]. It employed the use of a partial-thickness flap, leaving behind $0.5-0.75 \mathrm{~mm}$ of connective tissue and periosteum layer over the surrounding bone. This prevented the alveolar crestal bone loss and recession that usually occur following the reflection of a full-thickness mucoperiosteal flap [21]. Additionally, dual blood supply to the flap was ensured, from the underlying periosteal vasculature as well as from the flap's supraperiosteal vessels [22]. An epithelium-denuded surgical wound of $2-3 \mathrm{~mm}$ (depending on the extent of tissue displacement) was created on the palatal/lingual side of the surgical bed that healed by secondary intention.

A healing abutment firmly secured the flap, through a punch hole, and provided primary stability during its healing process. The final thickness of the keratinized mucosa depended on the thickness of the displaced flap. A follow-up period of 1 year was considered for this study, as maximum soft tissue changes occur around a dental implant during the first 6 months to 1 year [23]. Mild to moderate localized buccal horizontal depression (Seibert Class 1 ridge deficiency) [24] was corrected using this augmentation technique. Regardless of the soft tissue augmentation technique used, some degree of relapse and shrinkage of the initially augmented

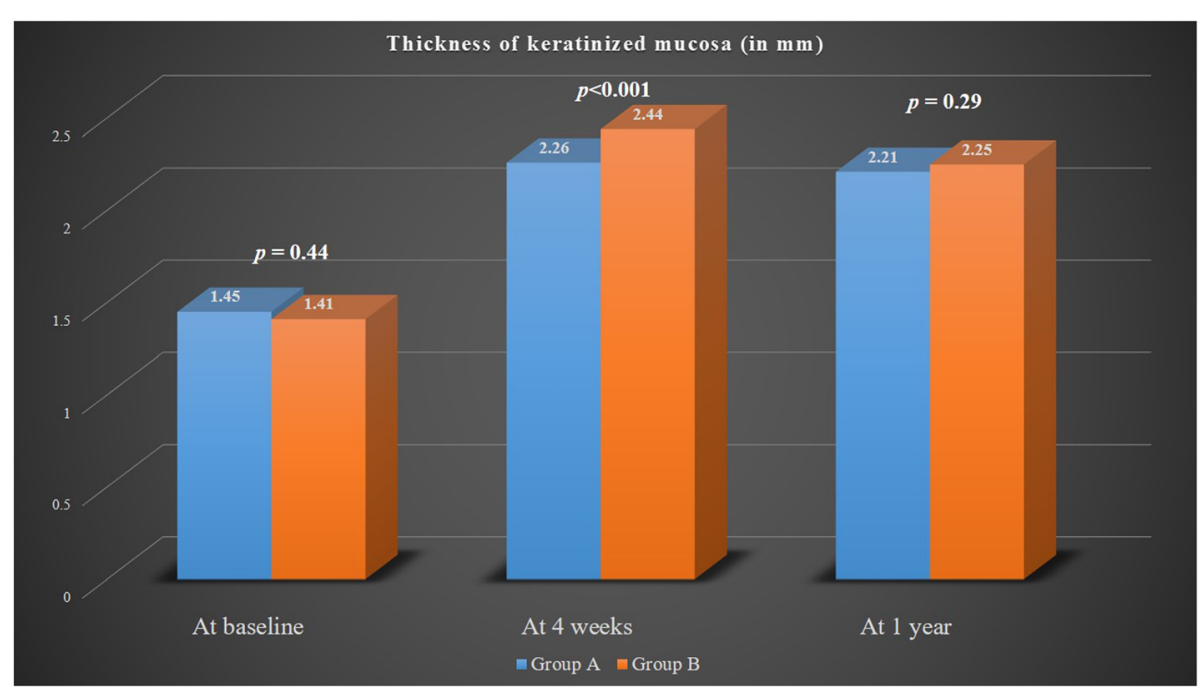

Fig. 5 Comparison of the thickness of keratinized mucosa between group A and group B at various time points 
keratinized mucosa is usually observed [25], as was seen in the subjects of our study at the 1 year follow-up visit.

A significant difference was seen in the post-operative pain, where the buccally displaced flap group experienced lesser discomfort than the sub-epithelial connective tissue graft group. This may be attributed to the fact that the buccally displaced flap technique did not need a secondary donor surgical site and was relatively atraumatic. Post-operative healing was devoid of the risk of slough formation of the superficial split-palatal flap, and thus, palatal pain. Furthermore, surgical procedures without sutures are usually considered minimally invasive by the patients and have a better acceptance [26].

In the present study, all procedures were performed by one surgeon. Thus, a surgeon-related bias may have been introduced as the surgeon has some "preferred" treatment procedure [27]. The limitations of this technique may include operator skill and experience in mucogingival surgical procedures. A high risk of flap perforation is also present in patients with a thin gingival biotype. Furthermore, although the study design was double-blinded, the subjects in group B had an additional surgical site (the hard palate) from where the sub-epithelial connective tissue graft was harvested, and thus were aware of the group they belonged to.

\section{Conclusion}

Within the limitations of the study, it was seen that the buccally displaced flap technique increased the width and thickness of the keratinized mucosa around implants over the observation period of 1 year, which was comparable to the subepithelial connective tissue graft. The surgical technique caused minimal patient discomfort and may be routinely employed to augment the peri-implant soft tissues.

\section{Supplementary information}

Supplementary information accompanies this paper at https://doi.org/10. 1186/s40729-020-00244-4.

Additional file 1. Buccally displaced flap surgical technique

\section{Acknowledgements}

Not applicable

\section{Authors' contributions}

N.P. and N.Y. conceived the ideas. N.P. and L.M. collected the data. N.P. and L.M. analysed the data. N.P. and N.Y. led to the writing. L.M. and N.Y. edited the manuscript. The authors read and approved the final manuscript.

\section{Funding}

Not applicable

\section{Availability of data and materials}

Data sharing is not applicable to this article as no datasets were generated or analysed during the current study,
Ethics approval and consent to participate

Ethical approval was sought for the study from the Intersystem Biomedica Ethics Committee with reference number ISBEC/NR-13/KM-VM/2018.

\section{Consent for publication}

Not applicable

\section{Competing interests}

Ninad Milind Padhye, Lopa Kishor Mehta, and Naveeta Yadav declare that they have no competing interests.

\section{Author details}

${ }^{1}$ Ceramco Dental Care, Andheri West, Mumbai, Maharashtra, India. ${ }^{2}$ King Edward Memorial Hospital, Mumbai, Maharashtra, India. ${ }^{3}$ Mahatma Gandhi Postgraduate Institute of Dental Sciences, Pondicherry, India.

Received: 14 March 2020 Accepted: 8 July 2020

Published online: 01 September 2020

\section{References}

1. Lekovic V, Kenney EB, Weinlaender M, Han T, Klokkevold P, Nedic M, et al. A bone regenerative approach to alveolar ridge maintenance following tooth extraction. Report of 10 cases. J Periodontol. 1997;68(6):563-70.

2. Camargo PM, Lekovic V, Weinlaender M, Klokkevold PR, Kenney EB, Dimitrijevic B, et al. Influence of bioactive glass on changes in alveolar process dimensions after exodontia. Oral Surg Oral Med Oral Pathol Oral Radiol Endod. 2000;90(5):581-6.

3. Araujo MG, Lindhe J. Ridge alterations following tooth extraction with and without flap elevation: an experimental study in the dog. Clin Oral Implants Res. 2009:20(6):545-9.

4. Landsberg CJ. Socket seal surgery combined with immediate implant placement: a novel approach for single-tooth replacement. Int J Periodontics Restorative Dent. 1997:17(2):140-9.

5. Bhatavadekar NB. Peri-implant soft tissue management: where are we? J Indian Soc Periodontol. 2012;16(4):623-7.

6. Chung DM, Oh TJ, Shotwell JL, Misch CE, Wang HL. Significance of keratinized mucosa in maintenance of dental implants with different surfaces. J Periodontol. 2006;77(8):1410-20.

7. Abrams L. Augmentation of the deformed residual edentulous ridge for fixed prosthesis. Compend Contin Educ Gen Dent. 1980;1(3):205-13.

8. Kulkarni MR, Bakshi PV, Kavlekar AS, Thakur SL. Applications of a modified palatal roll flap in peri-implant soft-tissue augmentation-a case series. J Indian Soc Periodontol. 2017;21(4):333-6.

9. Jiang $X$, Lin $Y$. Gain of keratinized mucosa around implants in the posterior mandible by a modified apically positioned flap and xenogeneic collagen matrix. Int J Periodontics Restorative Dent. 2019;39(5):721-7.

10. Misch CE, Al-Shammari KF, Wang HL. Creation of interimplant papillae through a split-finger technique. Implant Dent. 2004:13(1):20-7.

11. Gluckman H, Salama M, Du Toit J. Esthetic tunnel exposure: a combination technique for peri-implant soft tissue development at second-stage surgery. J Prosthet Dent. 2019;121(4):586-9.

12. Nemcovsky CE, Moses O. Rotated palatal flap. A surgical approach to increase keratinized tissue width in maxillary implant uncovering: technique and clinical evaluation. Int J Periodontics Restorative Dent. 2002;22(6):607-12.

13. Temmerman A, Cleeren GJ, Castro AB, Teughels W, Quirynen M. L-PRF for increasing the width of keratinized mucosa around implants: a split-mouth, randomized, controlled pilot clinical trial. J Periodontal Res. 2018;53(5):793800. https://doi.org/10.1111/jre.12568.

14. Jensen MP, Miller L, Fisher LD. Assessment of pain during medical procedures: a comparison of three scales. Clin J Pain. 1998;14(4):343-9.

15. Li L, Liu X, Herr K. Postoperative pain intensity assessment: a comparison of four scales in Chinese adults. Pain Med. 2007;8(3):223-34.

16. Thoma DS, Benić Gl, Zwahlen M, Hämmerle $\mathrm{CH}$, Jung RE. A systematic review assessing soft tissue augmentation techniques. Clin Oral Implants Res. 2009;20(Suppl 4):146-65.

17. Cardaropoli G, Lekholm U, Wennström JL. Tissue alterations at implantsupported single-tooth replacements: a 1-year prospective clinical study. Clin Oral Implants Res. 2006;17(2):165-71.

18. Schwarz F, Claus C, Becker K. Correlation between horizontal mucosal thickness and probing depths at healthy and diseased implant sites. Clin Oral Implants Res. 2017;28(9):1158-63. 
19. Ruggeri A, Franchi M, Trisi P, Piattelli A. Histologic and ultrastructural findings of gingival circular ligament surrounding osseointegrated nonsubmerged loaded titanium implants. Int J Oral Maxillofac Implants. 1994:9:636-43.

20. Reddy VK, Parthasarathy H, Lochana P. Evaluating the clinical and esthetic outcome of apically positioned flap technique in augmentation of keratinized gingiva around dental implants. Contemp Clin Dent. 2013;4(3): 319-24.

21. Fickl S, Kebschull M, Schupbach P, Zuhr O, Schlagenhauf U, Hurzeler M. Bone loss after full-thickness and partial-thickness flap elevation. J Clin Periodontol. 2011;38(2):157-62.

22. von Arx T, Salvi GE. Incision techniques and flap designs for apical surgery in the anterior maxilla. Eur J Esthet Dent. 2008;3(2):110-26.

23. Hanser T, Khoury F. Alveolar ridge contouring with free connective tissue graft at implant placement: a 5-year consecutive clinical study. Int J Periodontics Restorative Dent. 2016;36(4):465-73.

24. Seibert JS. Reconstruction of deformed, partially edentulous ridges, using full thickness onlay grafts. Part I. technique and wound healing. Compend Contin Educ Dent. 1983;4(5):437-53.

25. Halperin-Sternfeld M, Zigdon-Giladi H, Machtei EE. The association between shallow vestibular depth and peri-implant parameters; a retrospective 6 years longitudinal study. J Clin Periodontol. 2016:43(3):305-10.

26. Fortin T, Bosson JL, Isidori M, Blanchet E. Effect of flapless surgery on pain experienced in implant placement using an image-guided system. Int J Oral Maxillofac Implants. 2006;21(2):298-304.

27. Vercruyssen M, De Laat A, Coucke W, Quirynen M. An RCT comparing patient-centred outcome variables of guided surgery (bone or mucosa supported) with conventional implant placement. J Clin Periodontol. 2014; 41(7):724-32.

\section{Publisher's Note}

Springer Nature remains neutral with regard to jurisdictional claims in published maps and institutional affiliations.

\section{Submit your manuscript to a SpringerOpen ${ }^{\circ}$ journal and benefit from:}

- Convenient online submission

- Rigorous peer review

- Open access: articles freely available online

- High visibility within the field

Retaining the copyright to your article

Submit your next manuscript at $\boldsymbol{\nabla}$ springeropen.com 